\title{
Laundering Illegally Seized Evidence Through the Federal Sentencing Guidelines
}

\author{
Todd Flaming $\dagger$
}

In November of 1987, the United States Sentencing Guidelines took effect and revamped sentencing. Previously, sentencing judges had almost complete discretion in deciding the length of a defendant's sentence and based their decisions on an inquiry into the whole character of each defendant. The Guidelines prevent judges from conducting such wide inquiries into a defendant's character. Instead, they require the judge to apply a base level sentence for the crime, adding or subtracting years according to the Guidelines' list of "relevant conduct" factors.

In changing the nature of sentencing, the Guidelines created some new questions. For instance, what happens to evidence that the police have seized without a search warrant? The exclusionary rule forbids the use of such evidence at trial, but does not apply at all non-trial proceedings. Prior to the Guidelines, the rule rarely applied at sentencing. The sentencing judge always considered illegally seized evidence, even if that evidence had been excluded at trial, unless when seizing that evidence the police committed an unusually lawless violation of the Fourth Amendment; an occurrence shown so rarely that the exception has proved a paper tiger.

But under the Guidelines, the traditional rule admitting illegally seized evidence at sentencing presents a unique problem, illustrated by United States v McCrory. ${ }^{1}$ Police arrested Keith McCrory for selling a small amount of crack cocaine on the street. When the police came to arrest McCrory for this violation, they broke into his home without a search warrant and seized a large cache of drugs and guns. A jury found McCrory guilty of selling the small amount of crack. In the sentencing proceeding, the prosecution introduced the illegally seized drugs and guns, which were not introduced at trial, as evidence of "relevant conduct." Using the Guidelines, the judge sentenced McCrory to a term nine times

† B.A. 1988, Loyola Marymount University; J.D. Candidate 1993, The University of Chicago.

I 930 F2d 63, 64-66 (DC Cir 1991). Section III opens with a detailed description of this case. 
longer than McCrory would have served if he had only been convicted of selling the small package of crack. McCrory's new sentence roughly equalled that which he would have received had he been found guilty at trial of possessing the drugs and guns in the first place. In contrast, under the pre-Guidelines regime the effect of the illegally seized evidence would have been unpredictable. ${ }^{2}$

With the newly magnified importance of illegally seized evidence, should courts apply the exclusionary rule at sentencing? The exclusionary rule does not apply in all circumstances. In deciding whether to apply the exclusionary rule in a given evidentiary context or type of proceeding, the Supreme Court uses a balancing test that examines, on one side, the deterrence to police acting illegally and, on the other side, the need for the evidence. ${ }^{3}$ The Supreme Court has never decided whether the exclusionary rule applies at sentencing. Courts applying the balancing test have split on its application to post-Guidelines sentencing proceedings. Most courts find the exclusionary rule inapplicable at sentencing, allowing the introduction of illegally seized evidence. These "traditional rule" courts see the Guidelines as simply a newer version of the old sentencing regime and see no need to alter the old rule. Other courts argue that the new regime requires application of the exclusionary rule at sentencing. These "changed circumstances" courts insist that unless sentencing judges apply the exclusionary rule to relevant conduct evidence, excluding the evidence at trial in the first place is a mere formality.

Unfortunately, neither side has successfully reconciled its conclusions with both the Guidelines and the Supreme Court's balancing test. The "traditional rule" courts simply cite pre-Guidelines cases in applying the balancing test. The "changed circumstances" courts not only fail to apply both sides of the balancing test, but also ignore language in the Sentencing Reform Act and Guidelines that seems to prohibit the application of the exclusionary rule at sentencing.

This Comment addresses these shortcomings by proposing a new interpretation of the purpose and effect of the Guidelines. The Comment uses this perspective to properly apply the Supreme

\footnotetext{
${ }^{2}$ The sentence would probably have been lighter as well. See note 24 and accompanying text.

${ }^{3}$ Once the Supreme Court makes a determination that the exclusionary rule applies in a particular type of proceeding, or evidentiary context, lower courts usually must apply the rule without regard for the facts of the individual case. For instance, once the Court decided that the exclusionary rule did not apply to grand jury proceedings, lower courts could not balance case by case to decide whether to impose the exclusionary rule.
} 
Court's balancing test and to explain why the ambiguous language in the Act and Guidelines does not conflict with the exclusionary rule. It concludes that courts should apply the exclusionary rule at sentencing to the same extent that they apply the rule at trial.

Section I of this Comment explains the exclusionary rule by laying out the balancing test used by the Supreme Court to determine whether to create exceptions to the rule. It then describes pre-Guidelines cases that allowed the use of illegally seized evidence at sentencing. Section II discusses the Sentencing Guidelines, focusing on the way in which they changed sentencing. Section III explores the clash between the traditional rule and the Sentencing Guidelines. It then examines the approaches of the "traditional rule" and "changed circumstances" courts. Section IV suggests that both have misunderstood the Guidelines. That Section adopts a new view of the Guidelines for examining the relationship between the Guidelines and the exclusionary rule. From that viewpoint, Section V re-examines both the Supreme Court's balancing test and the statutory language. It concludes that the balancing test and the statute favor applying the exclusionary rule at sentencing.

\section{The Common law: The Exclusionary Rule and Sentencing}

A. What is the Exclusionary Rule?

The Fourth Amendment prohibits "unreasonable searches and seizures," but contains no enforcement provision. To fill this gap, the Supreme Court created the exclusionary rule. The exclusionary rule forbids the government from using evidence seized in violation of the Fourth Amendment against the victim of that seizure. ${ }^{5}$

But this judicially created remedy is not absolute. ${ }^{6}$ It applies in evidentiary contexts and types of proceedings where the Supreme Court has determined that "the rule's deterrent effect will be achieved, and has weighed the likelihood of such deterrence against the costs of withholding reliable information from the truth-seeking process." "The exclusionary rule exists only to deter

4 "The right of the people to be secure in their persons, houses, papers, and effects, against unreasonable searches and seizures, shall not be violated. . . " US Const, Amend IV.

- Weeks v United States, 232 US 383, 392-93 (1914); Mapp v Ohio, 367 US 643, 648-49 (1961).

Illinois v Krull, 480 US 340, 347 (1987).

7 Id. 
future unreasonable seizures and applies only in those evidentiary contexts and types of proceedings where it achieves that purpose. ${ }^{8}$

The Court first applied this "deterrence versus cost" balancing test in the 1974 case of United States $v$ Calandra. ${ }^{9}$ The Calandra Court held that the exclusionary rule should not apply during a grand jury proceeding. ${ }^{10}$ The Court reasoned that withholding illegally seized evidence from the grand jury would not add much to the deterrence gained from excluding the evidence at trial. Even with a grand jury indictment the prosecutor would still have to make his case at trial without the use of the illegally seized evidence. ${ }^{11}$ The Court held that the slight increase in deterrence that exclusion would produce did not weigh heavily against the resulting costs to the historical role of the grand jury, a role which demanded a wide ranging inquiry not bogged down by the traditional rules of evidence. ${ }^{12}$ Calandra articulated the current balancing test for deciding when to apply the exclusionary rule.

\section{B. The Traditional Rule: The Exclusionary Rule Does Not Apply at Sentencing}

The Supreme Court has expressly declined to decide whether the exclusionary rule applies at sentencing. ${ }^{13}$ The current rule has evolved from a series of lower court decisions spurred by two Ninth Circuit cases, Verdugo $v$ United States ${ }^{14}$ and United States $v$ Vandemark. ${ }^{15}$ In Verdugo, the Ninth Circuit remanded a case for resentencing, because the district court based the sentence on evidence that had been seized illegally by the police with the specific intention of increasing that sentence. ${ }^{16}$ The court observed that when the police decided to search Verdugo's home, the agents already had in their possession sufficient evidence to convict Verdugo of the original transaction. The court therefore inferred

8 Id; United States v Leon, 468 US 897, 906 (1984); Stone v Powell, 428 US 465, 486 (1976); United States v Calandra, 414 US 338, 347-48 (1974).

- 414 US at $348-49$.

${ }^{10}$ Id at 349.

11 Id at 351 .

12 Id at 349-52.

${ }^{13}$ United States $v$ Janis, 428 US 433,456 n 33 (1976). After applying the Calandra balancing test, the Janis Court declined to apply the exclusionary rule in the context of federal civil proceedings. Id at 447-54. The Court then stated: "We express no view on the issue of whether sentencing and parole revocation proceedings constitute 'civil proceedings' for the purposes of the principles announced in this opinion." Id at $456 \mathrm{n} 33$.

it 402 F2d 599 (9th Cir 1968).

1s 522 F2d 1019 (9th Cir 1975).

16 402 F2d at $610-13$. 
that the officers sought additional evidence not for arrest, but to locate a large supply of heroin that would be admissible in sentencing. ${ }^{17}$ The Ninth Circuit instructed the lower court not to rely upon the illegally seized evidence at sentencing. The holding keyed on the court's subjective determination that the particular police division, a highly-specialized narcotics unit, had a motive to ensure Verdugo's long-term incarceration. ${ }^{18}$

A later Ninth Circuit case, United States $v$ Vandemark, ${ }^{19}$ adopted the exception that swallowed the rule. Vandemark limited the application of Verdugo to "blatantly illegal" searches where the defendant could prove that the sole motive for seizing the evidence was to increase his sentence. ${ }^{20}$ Other circuits have generally accepted the Vandemark limitation, paying only lip service to the Verdugo holding. ${ }^{21}$ Practically, this limitation has proved decisive: in the twenty-four years since Verdugo, no defendant has been able to exclude evidence based on Verdugo. ${ }^{22}$

\section{A New Sentencing Regime}

Prior to November of 1987, the trial inquired into the crime; sentencing into the defendant's character. While stringent evidentiary and procedural standards governed the trial, sentencing proceeded in relative freedom. In fact, a sentence within statutory limits was not subject to review unless it was based on unconstitutional factors. ${ }^{23}$

12 Id at 612 .

18 Id.

10 522 F2d 1019.

20 Id at 1022-24. In Vandemark, the Ninth Circuit allowed the government to introduce at sentencing evidence the police obtained after an unconstitutional stop and search of the defendant's car. Id at 1020-21. While Vandemark used language suggesting that Verdugo would apply to all cases where the use of illegally seized evidence at sentencing "would provide a substantial incentive for unconstitutional searches and seizures," id at 1023, Vandemark actually distinguished Verdugo on three grounds: first, that Verdugo had involved a "blatantly illegal" and highly intrusive seizure, id at 1023; second, that the officers already had sufficient evidence for arrest, id at 1023-24; and third and "most importantly," that the evidence was seized for the sole purpose of enhancing the defendant's sentence, id at 1024.

22 While the Fourth and Fifth Circuits did not directly refer to Vandemark, they placed similar limitations on Verdugo. United States v Lee, 540 F2d 1205, 1212 (4th Cir 1976); United States v Butler, 680 F2d 1055, 1056 (5th Cir 1982). The Tenth Circuit directly cited Vandemark. United States v Graves, 785 F2d 870, 873-74 (10th Cir 1986). Prior to Vandemark, the Second Circuit had similarly limited Verdugo. United States $v$ Schipani, 435 F2d 26, 28 \& n 1 (2d Cir 1970).

${ }^{22}$ See United States $v$ Jewel, 947 F2d 224, 238 (7th Cir 1991) (Easterbrook concurring).

${ }^{23}$ United States v Tucker, 404 US 443, 446-47 (1972). 
This traditional regime forced the prosecutor to focus his energies on the trial alone. As Judge Easterbrook recently commented, "[t]o get a steep sentence the prosecutor needed to obtain a conviction on one very serious charge or multiple less serious ones. Excluding the evidence from the case in chief was a grievous, often mortal, blow."24

Congress levelled this century-old regime with the "sweeping reforms" ${ }^{25}$ of the Sentencing Reform Act of $1984 .{ }^{26}$ One of the central purposes of the Act was to reduce disparities in sentencing; often defendants convicted of seemingly similar crimes received vastly different sentences. ${ }^{27}$ Consequently, the Act created the United States Sentencing Commission and empowered it to develop guidelines for judges to use when sentencing. ${ }^{28}$

Under this authority, the Commission enacted the Federal Sentencing Guidelines ${ }^{29}$ and fundamentally changed the nature and goals of sentencing by making "all sentences basically determinate." 30 Under the Guidelines, the judge must impose the sentence indicated by the Guidelines' matrix. The matrix assigns a base number according to the nature and severity of the conviction crime and lists a variety of "relevant conduct" factors that add to or subtract from the base number; the number that emerges provides a narrow range within which the judge selects the defendant's sentence. ${ }^{31}$

\section{A Clash Between the Exclustonary Rule and the Guidelines and Two Lines of Judicial Answers}

\section{A. An Old Rule in a New Regime}

The traditional rule, established in Vandemark, ${ }^{32}$ allowed the sentencing judge to consider illegally seized evidence that would not have been admissible at trial. Vandemark would have barred

24 Jewel, 947 F2d at 239 (Easterbrook concurring).

${ }^{25}$ Mistretta $v$ United States, 488 US 361, 366 (1989).

${ }^{28}$ Pub L No 98-473, 98 Stat 1837,1987 (1984), codified as amended at 18 USC $\$ \S 3551-$ 3673 (1988); 28 USC $\$ \$ 991-998$ (1988). The Sentencing Reform Act was part of the Comprehensive Crime Control Act of 1984, Pub L No 98-472, 98 Stat 1837, 1976 (1984).

${ }^{27}$ See S Rep No 98-225, 98th Cong, 1st Sess 38-39 (Oct 11, 1984), in 1984 USCCAN $3182,3221-22$.

${ }^{28}$ See 28 USC $\$ \S 991,994$ (a) (1988).

${ }^{28} \mathrm{~S}$ Rep No $98-225$ at $63-64$, in 1984 USCCAN at 3246-47.

${ }^{30}$ Mistretta, 488 US at 367.

s1 See United States Sentencing Commission, Federal Sentencing Guidelines Manual $\S \S 1 \mathrm{B1.1}$ through 1B1.10 (West, 1990) ("Guidelines Manual").

${ }^{32} 522$ F2d at 1022-24. 
the illegally seized evidence only had the defendant shown that the evidence had been seized solely to increase the sentence, a barrier so formidable that it has not been overcome in any case since. Since the enactment of the Guidelines, four circuits-the Second, Third, District of Columbia, and Eleventh-have decided in favor of retaining Vandemark's traditional rule. ${ }^{33}$ Each of these "traditional rule" courts agreed that the exclusionary rule would apply in only the rarest of circumstances, if at all, and each allowed the use of illegally seized evidence at sentencing.

That four circuits have confronted in one year an issue that had been dormant for over two decades suggests that courts have suddenly become uneasy with the traditional rule. Yet few courts have been willing to reverse course. Only two district court decisions, one of which was recently vacated, and a concurring opinion in the Seventh Circuit have abandoned the traditional rule in the post-Guidelines world. ${ }^{34}$ These "changed circumstances" opinions understood that the Guidelines altered sentencing enough that a post-Guidelines judge must apply the exclusionary rule to illegally seized evidence.

Though contradictory, these cases all share a common thread. Both the "traditional rule" and "changed circumstances" cases reveal the irony of giving illegally seized evidence essentially the same effect when used to calculate a sentence as it would have had if introduced at trial. The case introduced at the beginning of this Comment, $\mathrm{McCrory},{ }^{35}$ provides a good example of this irony.

In that case, two undercover officers bought a small amount of crack cocaine from McCrory. After leaving him, they broadcast the location of his apartment and a "veritable SWAT team descended upon it, carrying everything except a search warrant, and conducted what the government [] conceded was an unconstitutional search in which they found a large cache of drugs and guns." ${ }^{36}$ The prosecutor introduced the additional evidence at sentencing as "relevant conduct" under the Guidelines. The evidence increased McCrory's sentence from a range of twenty-seven to thirty-three

${ }^{33}$ United States v Tejada, 956 F2d 1256, 1263 (2d Cir 1992); United States v Torres, 926 F2d 321, 325 (3d Cir 1991); United States v Lynch, 934 F2d 1226, 1237 (11th Cir 1991), cert denied, 112 S Ct 885 (1992); United States v McCrory, 930 F2d 63, 69 (DC Cir 1991), cert denied, 112 S Ct 885 (1992).

34 United States v Cabrera, 756 F Supp 134, 135-36 (S D NY 1991), vacated in part by Tejada, 956 F2d 1256; United States v Rullo, 748 F Supp 36, 45 n 6 (D Mass 1990); Jewel, 947 F2d at 238-40 (Easterbrook concurring).

ss 930 F2d 63 (DC Cir 1991).

${ }^{36}$ Id at 70 (Silberman concurring). 
months to a range of 235 to 293 months. Had the prosecution charged and convicted McCrory of the additional crimes based on the illegally seized evidence at trial, he would have faced a sentence of 248 to 295 months. ${ }^{37}$ Note that the top range of this hypothetical sentence differs from his actual sentence by only two months.

This ironic result allows the prosecution to evade the exclusionary rule. In the post-Guidelines world, the prosecutor can achieve almost exactly the same sentence with illegally seized evidence introduced at sentencing as he would have achieved if there were no exclusionary rule at all. Indeed, in contrast to the preGuidelines cases, the prosecution can calculate the effect of the illegally seized evidence with mathematical precision. Once the police make a simple street bust, the government has every incentive to search the defendant's property without a warrant.

The post-Guidelines sentencing regime so distorts the results under the traditional rule that it demands a re-evaluation of the need for the exclusionary rule at sentencing. In Calandra, the Supreme Court provided a balancing test for conducting this evaluation. Unfortunately, not one of the post-Guidelines cases has seriously examined both sides of the Supreme Court's exclusionary rule balancing test. The "traditional rule" courts that do not apply the exclusionary rule at sentencing stress the costs of exclusion, while the "changed circumstances" courts that do apply the exclusionary rule stress the loss in deterrence from allowing tainted evidence at sentencing. Consequently, the cases argue past each other, making resolution of the issue difficult. The rest of this Section analyzes and critiques these arguments.

\section{B. "Traditional Rule" Cases}

The four circuits that adhere to the traditional rule ${ }^{38}$ have advanced two arguments for not applying the exclusionary rule at sentencing: 1) the Calandra balance weighs against the rule; and 2) Congress statutorily resolved the issue. This Section evaluates these arguments.

${ }^{33}$ Id at 66 .

${ }^{38}$ The Second Circuit (Tejada, 956 F2d 1256), Third Circuit (Torres, 926 F2d 321), Eleventh Circuit (Lynch, 934 F2d 1226), and the D.C. Circuit (McCrory, 930 F2d 63). 
1. Arguments based on the Calandra balancing test.

Under the Calandra balancing test, the Supreme Court weighs deterrence of police misconduct against costs of exclusion when considering whether to apply the exclusionary rule. All four of the "traditional rule" courts concluded that excluding illegally seized evidence from sentencing would not add to the deterrence gained from exclusion at trial and that excluding such evidence would impose significant costs on the sentencing hearing. Therefore, they reasoned, courts should not exclude such evidence from sentencing. ${ }^{38}$ But these courts relied entirely on the conclusions of preGuidelines cases for authority on both sides of the balancing test. Not one of these courts seriously considered the effect of the Guidelines. The D.C. Circuit's McCrory opinion provides a good example of this.

In analyzing the deterrence side of the balancing test, the $M c C r o r y$ opinion merely asserted that excluding tainted evidence at sentencing would not add significantly to the deterrence gained from excluding such evidence at trial. ${ }^{40}$ To support this assertion, the opinion cited four pre-Guidelines cases ${ }^{41}$ and the Third Circuit's post-Guidelines case, United States $v$. Torres. ${ }^{42}$ Notably, the page in Torres to which the McCrory court cited contains a similarly flat assertion backed only by pre-Guidelines cases. ${ }^{43}$

Analysis on the costs side of the test also depended exclusively on pre-Guidelines authority. The McCrory opinion cited the 1949 case of Williams $v$ New York ${ }^{44}$ to support its argument that the sentencing judge has always enjoyed freedom from evidentiary requirements so that she may prescribe an appropriate sentence for the offender. ${ }^{45}$ The Williams Court had explained that sentencing served the unique function of tailoring the punishment to fit the offender; this value justified giving the sentencing judge more information than was available at trial. ${ }^{46}$ Yet the McCrory. court relied on that 1949 case for its conclusion that there is a unique

so Lynch, 934 F2d at 1236-37; Torres, 926 F2d at 324-25; McCrory, 930 F2d at 68-69; Tejada, $956 \mathrm{~F} 2 \mathrm{~d}$ at $1261-62$.

40 930 F2d at 68 .

11 Id at 68-69, citing United States $v$ Lee, 540 F2d 1205, 1211 (4th Cir 1976); United States $v$ Graves, 785 F2d 870, 873 (10th Cir 1986); United States v Butler, 680 F2d 1055 (5th Cir 1982); and United States $v$ Schipani, 435 F2d 26, 28 (2d Cir 1970).

42930 F2d at 68-69, citing Torres, 926 F2d at 325 .

43 Torres, 926 F2d at 325 .

4337 US 241 (1949).

45930 F2d at 68, citing Williams, 337 US at 246.

18337 US at $246-47$. 
value in providing the sentencing judge with access to the "fullest information." 47 The McCrory court made no attempt to analyze sentencing post-Guidelines to ensure that the reason for giving a sentencing judge full access to information still exists. Rather, the court apparently assumed that things have not changed. In step with $M c C r o r y$, the other "traditional rule" courts made the same assumption. ${ }^{48}$

2. Arguments that Congress resolved the issue.

"Traditional rule" courts also draw support from a provision of the Sentencing Reform Act which on its face appears to reject limitations like the exclusionary rule at sentencing. Section 3661 of Title 18 of the Code provides:

[n]o limitation shall be placed on the information concerning the background, character, and conduct of a person convicted of an offense which a court of the United States may receive and consider for the purpose of imposing an appropriate sentence. ${ }^{48}$

The "traditional rule" courts' reliance on $\S 3661$ might be read in two ways. Both ways, without more, beg the question. Under the first interpretation, the "traditional rule" courts would read § 3661 to say that Congress directly intended to bar the application of the exclusionary rule at sentencing. But, as Judge Easterbrook observed in his Jewel concurrence, since the exclusionary rule is a constitutional requirement, $\S 3661$ must bow to the extent it conflicts with the Fourth Amendment. ${ }^{50}$ Although the exclusionary rule is a judicially created remedy for Fourth Amendment violations, once the Calandra balancing test requires application of the rule, Congress cannot restrict application of the rule and leave an insufficient deterrent against Fourth Amendment violations.

Under the second interpretation, the "traditional rule" courts would read $\S 3661$ as a substantive grant of discretion to the sentencing judge. This grant might take two forms. Section 3661 might be read to trump the matrix produced by the Sentencing Commission, but that would render the Guidelines meaningless. If

42930 F2d at 68.

${ }^{18}$ Torres, 926 F2d at 324. Although Tejada and Lynch purported to recognize the effect of the Guidelines, at best they analyzed the Guidelines in a conclusory fashion. Tejada, 956 F2d at 1262-63; Lynch, 934 F2d at 1235-36.

1918 USC § 3661 (1988). See Tejada, 956 F2d at 1256; Lynch, 934 F2d at 1235-36; McCrory, 930 F2d at 68; Torres, 926 F2d at 324.

so 947 F2d at 238 (Easterbrook concurring). See also Mapp, 367 US at 648. 
judges could consider any information outside the framework of the Guidelines, the Guidelines would no longer definitively guide sentencing. Alternatively, $\S 3661$ might be seen as preserving the judge's discretion within the framework of the matrix. Here, the "traditional rule" courts use $\S 3661$ to argue that the Guidelines have not significantly altered the costs side of the Calandra balancing test. That is, even after the Guidelines, the exclusionary rule would unduly hamper the sentencing judge's freedom-freedom evidenced by the recodification of $\S 3661 .^{.11}$ Regardless of how much freedom to decide a sentence the judge actually has, these courts would argue, the existence alone of $\S 3661 \mathrm{dem}$ onstrates that the basic structure of sentencing has not changed. Even under this interpretation, reliance on $\S 3661$ begs the question. The court can only calculate how much diminishing the sentencing judge's discretion affects the costs side of the Calandra balancing test if it looks to the judge's actual discretion during sentencing. The courts cannot "fool" Calandra by using the language of $\S 3661$ to argue that the Guidelines have not diminished the judge's discretion when, in fact, they have. ${ }^{\mathbf{} 2}$

\section{C. "Changed Circumstances" Cases}

Why did four circuits suddenly need to reaffirm the traditional rule within the space of one year? Although only a few judges have been willing to challenge that rule, ${ }^{53}$ they make a powerful argument against the notion that the Guidelines have had no serious effect. They argue that, under the Guidelines, the traditional rule creates a back door for illegally seized evidence and thereby undermines deterrence.

But these "changed circumstances" opinions all leave out a critical part of the analysis, ignoring the costs side of the balancing

s1 See Tejada, 956 F2d at 1262.

s2 A variation of this argument is that the Guidelines themselves declare that there are no limits on the evidence a judge may consider, apart from that the evidence be reliable. Lynch, for example, cited \$ 6A1.3 of the Guidelines. That section reads: "In resolving any reasonable dispute concerning a factor important to the sentencing determination, the court may consider relevant information without regard to its admissibility under the rules of evidence at trial, provided that the information has sufficient indicia of reliability to support its probable accuracy." Lynch, 934 F2d at 1236. The Lynch court argued that § 6A1.3 demonstrates that the judge has the same level of discretion post-Guidelines as the judge had pre-Guidelines. But this argument is vulnerable to the same attack as the argument made under $\$ 3661$. The judge may consider only evidence about "a factor important to the sentencing determination." Section 6A1.3 does not reveal how much discretion the sentencing judge actually has in imposing the proper sentence.

s3 Cabrera, 756 F Supp at 135-36; Rullo, 748 F Supp at 45 n 6. 
test. This hole in their argument makes it vulnerable to an easy attack. A good example comes from the saga of the Cabrera case. In Cabrera, Judge Martin of the Southern District of New York argued that:

pre-guideline reasoning is not valid when applied to a sentencing scheme that requires the Court to provide specific increases in the sentencing level in specific factual settings. The existence of sentencing guidelines are well-known to police officers and federal agents and the impact of specific evidence on the sentence a defendant will receive surely cannot have escaped their notice. ${ }^{54}$

Judge Martin thus focused exclusively on the deterrence side of the test. He apparently assumed that the new sentencing regime undermines deterrence to such an extent that evaluating the other side of the balancing test, the costs side, is unnecessary. Judge Martin is correct in arguing that the regime greatly undermines deterrence. As Judge Silberman, the concurring judge in the $\mathrm{Mc}$ Crory case, observed, handing excluded evidence to the sentencing judge now effectively circumvents the exclusionary rule at trial: "a more patent end run around the exclusionary rule is hard to imagine."ss

But the Cabrera opinion did not address the costs side of the balancing test. As the Second Circuit pointed out in its vacating opinion, "the Supreme Court has instructed us not to suppress evidence solely because doing so might deter illegal searches. Rather, the likelihood of increased deterrence must be balanced against the considerable cost of excluding reliable information." the $M c C r o r y$ majority observed, precedent runs counter to arguments which rely solely on deterrence. ${ }^{57}$ The argument in the district court Cabrera opinion failed for this reason.

The pre-Guidelines cases identified a cost of excluding evidence at sentencing. They reasoned that the value of basing a defendant's sentence on the widest range of information possible weighs heavily against whatever decrease in deterrence may result from introducing the tainted evidence. The post-Guidelines "changed circumstances" cases leave this argument untouched.

\footnotetext{
54 756 F Supp at $135-36$.

so 930 F2d at 70 (Silberman concurring).

se Tejada, 956 F2d at 1261.

${ }^{87} 930$ F2d at 67.
} 
Therefore, the analysis in post-Guidelines opinions is incomplete. Without adequate answers to the "traditional rule" courts' argument that sentencing values having the widest available range of information about the defendant, these "changed circumstances" cases argue for the unconstitutionality of long-standing precedent on the basis of only a partial application of the current test.

\section{How the Guidelines Changed Sentencing}

When Congress passed the Sentencing Reform Act in 1984, it intended to lift the cloak of unfettered judicial discretion which allowed improper influences to enter into some sentencing decisions. Congress did not intend for the Guidelines to entirely replace the prior regime. But the Sentencing Commission's end product had precisely that effect. The Guidelines shifted sentencing's focus from an unbounded inquiry into the character of the defendant to a structured extension of the trial's inquiry into the crime.

This Comment proposes a new model of the Guidelines that views the Sentencing Reform Act as an effort to filter inappropriate information out of sentencing. This section employs this viewpoint to suggest that the end product of that effort, the Sentencing Commission's Guidelines, cut out information about the defendant's background and character. This new model sees the Guidelines as a rejection of the sentencing regime described by the Supreme Court in Williams $v$ New York. ${ }^{88}$ In the Williams era, the trial inquired into the crime and sentencing inquired into the whole character of the defendant. The Guidelines, on the other hand, filter out all but a few precisely-defined aspects of character.

\section{A. Exhuming Williams}

The 1949 Williams Court ruled that the constitutional rights of confrontation and cross-examination that applied at trial did not apply at sentencing. ${ }^{58}$ The Williams opinion centered on the Court's discussion about the difference between sentencing and trial. The Court reasoned that sentencing had historically been a proceeding different in nature from the trial. ${ }^{60}$ The significance of Williams lies not in its holding, but in the Court's discussion of why sentencing and trial were by definition different.

\footnotetext{
s8 337 US 241 (1949).

68 Id at 250-51.

Bo Id at 246.
} 
The Court offered three reasons to separate the trial from the sentencing. First, it saw the trial as an inquiry into the crime and sentencing as an inquiry into the character of the defendant. ${ }^{61}$ Sentencing fulfilled a specific purpose: "the punishment should fit the offender and not merely the crime." 62 The outcome of the trial inquiry (the conviction) provided the judge with the basis for the sentence; the sentencing inquiry served the purpose of altering that number based on the character of the person being convicted..$^{63}$

Second, the Williams Court justified a wide-open inquiry into the defendant's character as a way to help rehabilitate the defendant. Full information allowed the sentencing judge to prescribe "rehabilitation of those who respond to treatment and the permanent isolation of those who do not react." Court saw punishment as primarily a rehabilitative venture. In such a regime, the sentencing judge should have a full folder of information from which to diagnose a defendant and prescribe the appropriate rehabilitative medicine.

Third, the Williams majority recognized the intuitive quality of the sentencing judge's discretion. The Court observed that the sentencing judge "could exercise a wide discretion in the sources and types of evidence used to assist him in determining" the punishment. ${ }^{65}$ According to the Williams Court, a sentence reflected the judge's insight into the defendant's character, informed by the intuitive insight provided by this wide ranging inquiry. ${ }^{66}$ This policy explains why a sentence, if within statutory limits, was not subject to review. ${ }^{67}$

B. The Guidelines

Unreviewable discretion comes at a price. Concerned with seemingly arbitrary disparities in sentencing imposed on defend-

B1 Id at 247.

${ }^{62}$ Id.

33 Id at 246-49.

4d It 247 n 8, citing Sheldon Glueck, Principles of a Rational Penal Code, 41 Harv L Rev 453, 463 (1928).

6s Id at 246.

66 Id at 248.

${ }^{67}$ See United States v Tucker, 404 US 443, 447 (1972) (a "sentence imposed by a federal district judge, if within statutory limits, is generally not subject to review" if constitutional). 
ants who had committed facially similar crimes, ${ }^{88}$ Congress sought to curtail significantly what it thought to be the source of the problem: unfettered judicial discretion. ${ }^{69}$ Congress intended the Sentencing Reform Act to bring equality to the sentencing hearing by altering the procedure. The Guidelines accomplish this goal by telling the judge specifically what she may consider and what she may not, thereby filtering out the impurities that may hide behind judicial discretion. As two commentators have observed, " $[t]$ he primary purpose of the Sentencing Reform Act and the sentencing guidelines is to bring about equality of punishment, so that similarly situated defendants convicted of similar offenses are similarly punished."7o

Under the Guidelines, the relationship between trial and sentencing contrasts sharply with that described in Williams. First, the Guidelines regime shifted sentencing from a character-based inquiry to a crime-based inquiry. Congress wanted the Commission to retain considerations of character, but remove them from the sentencing judge's ad hoc discretion. Congress directed the Commission to build offender characteristics such as age, education, vocational skills, mental or emotional condition, drug dependence, employment record, family ties and responsibilities, community ties, and criminal history into the sentencing matrix. ${ }^{21}$ Congress wanted the Guidelines to "reflect the general inappropriateness" of individual sentencing judges considering-on an ad hoc basis-aspects of the defendant's character, or whole person ("education, vocational skills, employment record, family ties and responsibilities, and community ties of the defendant"). ${ }^{72}$ Congress thus codified into the Sentencing Reform Act its statutory goal of filtering inappropriate information out of sentencing by instructing the Commission to develop uniform policies for addressing these factors and to ensure that these factors were not left to the ad hoc determinations of the individual sentencing judge. Congress handed character decisions over to the Sentencing Commission to

${ }^{68}$ Cheryl Q. Bader and David S. Douglas, Where to Draw the Guideline: Factoring the Fruits of Illegal Searches Into Sentencing Guidelines Calculations, 7 Touro L Rev 1, 19-20 (1990).

${ }^{68} \mathrm{~S}$ Rep No 98-225 at 38-39, in 1984 USCCAN at 3221-22 (cited in note 27) ("These ،disparities, whether they occur at the time of the initial sentencing or at the parole stage, can be traced directly to the unfettered discretion the law confers on those judges and parole authorities responsible for imposing and implementing the sentence.").

so Bader and Douglas, 7 Touro L Rev at 3 \& $n 7$.

7 See 28 USC \& 994(d) (1988).

${ }^{72}$ See 28 USC $\$ 994(\mathrm{e})$ (1988). 
be appropriately considered and reflected in a limited way within the framework of the Guidelines.

The Commission took this ball and ran with it. The resulting Guidelines barely pay lip service to the defendant's character. Apparently, the Commission had inadequate information on the influence of offender characteristics in sentencing and, pressed for time, "created very restrictive policies that put the onus on judges to articulate valid reasons for giving sentencing effect to personal characteristics." 73 The Guidelines Handbook confirms the new emphasis: "[a]mong the only offender characteristics taken into consideration by the Guidelines are the defendant's criminal record and criminal livelihood, which will enhance the sentencing range, and the defendant's acceptance of responsibility for the crime, which will lower the range." ${ }^{74}$ Some courts read the Guidelines to bar any consideration of offender characteristics. ${ }^{75}$ Hence, spurred by Congress's push to remove improper considerations from sentencing, the Commission effectively took the character inquiry away altogether.

The second change the Guidelines made was a shift away from rehabilitation as a goal of sentencing. The Commission's introduction to the Guidelines speaks only of the goals of "control of crime," "deterr[ence]," "incapacita[tion]," and giving offenders their "just deserts." "Any mention of "rehabilitation" is conspicuously absent.

The third change the Guidelines brought about was a rejection of intuitive sentencing as described in Williams. The Guidelines all but eliminated the sentencing judge's unfettered discretion, which had previously served to ensure that the punishment fit the offender. The Guidelines clearly reflect this policy. They do allow a judge to depart from the determined sentence when she finds that the Sentencing Commission failed to adequately take into account aggravating or mitigating circumstances that warrant departure. ${ }^{77}$

${ }^{73}$ Theresa Walker Karle and Thomas Sager, Are the Federal Sentencing Guidelines Meeting Congressional Goals?: An Empirical and Case Law Analysis, 40 Emory L J 393, 433 (1991).

74 Wayne Barr and Laurel M. Cohn, eds, Federal Sentencing Guidelines Handbook $\S 1.01$ at 5 (McGraw-Hill, 1990) ("Guidelines Handbook") (citations omitted). See Guidelines Manual §§ 3B1.1 through 3B1.4 at 201-03; and §§ 5H1.1 through 5H1.10 at 269-71; and $\S 3 \mathrm{E} 1$ at $219-20$ (cited in note 31 ).

${ }_{75}$ See, for example, United States v Brewer, 899 F2d 503, 506 (6th Cir 1990).

- 76 Guidelines Manual at 3-4 (cited in note 31).

7718 USC \& 3553(b) (1988). 
But such departure is not intended to be common, ${ }^{78}$ and the judge must state in open court her specific reasons for departing. ${ }^{79}$ As Judge Easterbrook has observed, "[i]nstead of a wide-ranging inquiry into the defendant's character in which 'the punishment should fit the offender and not merely the crime,' sentencing has become a focused inquiry into the defendant's crimes."

The suggested "filter" viewpoint, described above, illustrates that the Commisssion did not design the Guidelines merely to tighten up sentencing for the sake of uniformity. Rather, they were the result of an effort to filter out of sentencing the wrong reasons, such as race, for imposing one sentence over another. ${ }^{81}$ Viewed from this vantage point, one can easily see why Congress and the Sentencing Commission factored character considerations out of the sentence and imposed rigid requirements that eliminate the "intuitive" quality of the sentence.

\section{How the Rejection of Character-Based Sentencing Affects the Exclusionary Rule ANalysis}

Analyzing the Sentencing Reform Act and the Guidelines as an elaborate "filter" highlights how they operationally rejected sentencing's historical function. This Section applies the "filter" viewpoint to suggest two ramifications of the Guidelines: 1) courts should resolve the Calandra balancing test in favor of applying the exclusionary rule at sentencing; and 2) courts can legitimately read $\S 3661$ as subordinate to the exclusionary rule without ruling it unconstitutional.

78 The Commission intended departures in only "atypical" and "unusual" cases. Thomas W. Hutchison and David Yellen, Federal Sentencing Law and Practice 7 (West, Supp 1991).

79 18 USC \& 3553(c) (1988).

so Jewel, 947 F2d at 239-40 (Easterbrook concurring), citing Williams, 337 US at 24647.

s Race accounts for a great deal of disparity in sentencing. A well-known exarnple of this problem comes from a study which showed that, in Georgia, defendants charged with killing white persons were one and a half times as likely to receive the death penalty as defendants charged with killing black persons. David C. Baldus, George Woodworth, and Charles Pulaski, Equal Justice and the Death Penalty: A Legal and Empirical Analysis 144 (Northwestern, 1989). Other studies show similar racial disparities throughout sentencing. See Cassia Spohn, John Gruhl, and Susan Welch, The Effect of Race on Sentencing: $A$ Re-examination of an Unsettled Question, 16 Law \& Society Rev 71 (1981-82). 


\section{A. Applying Calandra Balancing}

1. Deterrence.

The Calandra balancing test requires the exclusionary rule where the deterrence benefit of the exclusion in the particular circumstance outweighs the costs of withholding reliable information in that circumstance. ${ }^{82}$ The most recent Supreme Court exclusionary rule case, James $v$ Illinois, rejected the use of illegally seized evidence to impeach a defense witness's testimony and distinguished a previous case in which the Court allowed illegally seized evidence to impeach the defendant's testimony. ${ }^{83}$ On the costs side of the test, the James Court reasoned that since a criminal defendant will more likely lie on the stand and risk a perjury charge than a witness, excluding evidence impeaching a defendant has a greater cost than excluding evidence impeaching a witness. ${ }^{84}$ More importantly, for present purposes, in evaluating deterrence of police misconduct, the James Court stated:

[M] uch if not most of the time, police officers confront opportunities to obtain evidence illegally after they have already legally obtained (or know that they have other means of legally obtaining) sufficient evidence to sustain a prima facie case. In these situations, a rule requiring exclusion of illegally obtained evidence from only the government's case in chief would leave officers with little to lose and much to gain by overstepping constitutional limits on evidence gathering. Narrowing the exclusionary rule in this manner, therefore, would significantly undermine the rule's ability to "compel respect for the constitutional guarantee in the only effectively available way-by removing the incentive to disregard it."

The James analysis lays out a standard for deciding when allowing tainted evidence undercuts the deterrent value of the rule enough to reject the use of the tainted evidence. The James Court recognized a serious problem with allowing illegally seized evidence where police officers already possess evidence adequate to establish a prima facie case. The Court thought the need for deterrence greatest when police face the highest temptation to seize evidence illegally. ${ }^{86}$

\footnotetext{
${ }^{82}$ United States $v$ Calandra, 414 US 338, 347-49 (1974).

s3 493 US 307, 320 (1990), distinguishing Walder $v$ United States, 347 US 62, 65 (1954).

s4 493 US at $314-15$.

ss Id at 319 (citations and footnote omitted).

${ }^{86}$ Id.
} 
Sentencing under the Guidelines presents a paradigmatic example of a situation that meets the James standard for three reasons. First, a real offense system, as presented by the Guidelines, increases incentives to seize evidence by "overstepping constitutional limits on evidence gathering." Second, the certainty of an increased sentence with illegally seized evidence raises the incentives to acquire it. Finally, the police know well the effects of the Guidelines.

a) Real offense systems. The Guidelines impose a "real offense" system. ${ }^{87}$ In contrast to a charge offense system, which bases a defendant's sentence on the crime charged regardless of what crime he actually committed, a real offense system bases a defendant's sentence on the crime actually committed regardless of the crime charged.

For example, the sentence of a defendant convicted of possession of a small amount of cocaine may be based on an additional amount of cocaine that the defendant possessed, but which was never introduced at trial. If his sentence term imposed by the Guidelines is as long as the term he would have received for conviction of possessing the additional cocaine in the first place, his sentence is based on a real offense calculation. Such a result, which is common under the Guidelines, makes introducing illegally seized evidence at sentencing as attractive as at trial. Moreover, evidence introduced at sentencing is generally subject to a lower standard of proof. $^{88}$ Therefore, prosecutors strategically opt to save questionable evidence for sentencing once there is enough evidence to establish a simple drug conviction.

b) Certainty of Guidelines' application. The certainty of the Guidelines' application also increases the incentive to offer illegally seized evidence to the sentencing judge. Judges seldom de-

${ }^{87}$ Guidelines Handbook $\$ 1.01$ at 5 (cited in note 74). The Guidelines Handbook cites the Second Circuit for the proposition that the Guidelines generally "adopt [a] charge offense method but contain sufficient elements of [a] real offense method to allow courts to look at facts in determining [a] sentence." Id, citing United States $v$ Correa-Vargas, 860 F2d 35 (2d Cir 1988). Nevertheless, the "relevant conduct" provision in the Guidelines Manual, $\$ 1 \mathrm{~B} 1.3$, the provision on which this Comment focuses, ensures a real offense conviction in practice. See Comment, The Federal Sentencing Guidelines: Adopting Clear and Convincing Evidence as the Burden of Proof, 57 U Chi L Rev 1387, 1390 (1990).

${ }^{88}$ See Comment, $57 \mathrm{U}$ Chi L Rev at 1394. 
part from matrix-determined sentences. ${ }^{89}$ Consequently, a police officer knows that any additional relevant evidence will enhance the sentence. With increased certainty about the effect of introducing an additional piece of evidence, the officer's incentive to conduct an illegal search increases. Pre-Guidelines courts reasoned that a law enforcement officer would be unlikely to engage in an illegal seizure for enhancing a defendant's sentence. This reasoning does not apply post-Guidelines. As Judge Martin explained in Cabrera:

That reasoning was valid when applied to a sentencing structure that gave the district judge almost unlimited discretion in selecting a sentence below the statutory maximum, including the discretion to consider or not consider suppressed evidence. This pre-guideline reasoning is not valid when applied to a sentencing scheme that requires the Court to provide specific increases in the sentencing level in specific factual settings. ${ }^{90}$

c) Police knowledge of the Guidelines' effects. Unlike the evidentiary rules of witness impeachment, the "existence of sentencing guidelines are [sic] well-known to police officers and federal agents and the impact of specific evidence on the sentence a defendant will receive surely cannot have escaped their notice."91 The Guidelines operate in a relatively straightforward manner, ${ }^{92}$ and the Commission actively trains teams of investigators how to navigate through the sentencing matrix..$^{33}$

\footnotetext{
${ }^{80}$ The most recent study shows sentences involving departures from the Guidelines' range occurred $16.6 \%$ of the time. 1990 United States Sentencing Commission Annual Report 69.

so 756 F Supp at 135 (citation omitted).

${ }^{91}$ Id at 135-36. As an example, Judge Martin cited United States $v$ Bye, 919 F2d 6 (2d Cir 1990), where an agent testified to advising a defendant that his sentence would be calculated on the basis of a quantity of narcotics. Id at 7 . The effectiveness of the exclusionary rule on individual officers depends to a great extent on the amount of information available to them. Where the officer knows the reasons for rejection of evidence, the officer is more likely to be deterred in that situation. See Comment, The Exclusionary Rule and Deterrence: An Empirical Study of Chicago Narcotics Officers, 54 U Chi L Rev 1016, 1033-41 (1987). Likewise, awareness of specific situations where evidence will have an effect on the sentence should increase incentives to search for that evidence.

${ }^{92}$ See William W. Wilkins, Jr. and John R. Steer, Relevant Conduct: The Cornerstone of the Federal Sentencing Guidelines, 41 SC L Rev 495 (1990), for an overview of the postGuidelines sentencing procedure.

${ }^{93}$ The Act authorized the Sentencing Commission to "devise and conduct periodic training programs of instruction in sentencing techniques for judicial and probation personnel and other persons connected with the sentencing process." 28 USC § 995(a)(18) (1988). The Sentencing Commission, in 1990, "provided training to approximately 4,028 individuals
} 
Moreover, the police officers involved in the cases usually at issue here-drug cases-readily know when they have enough evidence for a prima facie case against the defendant. Since all that is needed to get additional evidence in at sentencing is a minor drug conviction, one arrest for simple possession sufficiently establishes a prima facie case. Once the police caught McCrory selling a small amount of crack, they ordered the warrantless search of his house.

d) Experience under the Guidelines. The Guidelines make seizing evidence in violation of the Fourth Amendment extremely attractive to police once there is a street bust for possession of drugs. Moreover, the structure and effect of the Guidelines are well known to police officers. Thus, sentencing under the Guidelines is a textbook example of a case where the likelihood of deterrence from excluding evidence is high. In theory, without excluding illegally seized evidence at sentencing, any deterrence gained from excluding that evidence at trial disappears.

Experience under the Guidelines vindicates this analysis. The prosecution in McCrory introduced enough evidence of "relevant conduct" to increase McCrory's sentence nine fold. McCrory is not unusual. In Torres, the additional evidence was a kilogram of cocaine. ${ }^{94}$ In Lynch, the prosecutor introduced illegally seized handguns to the sentencing judge after the jury had acquitted Lynch of all firearms counts. ${ }^{95}$ In Cabrera, the prosecutor offered an additional kilogram of cocaine and a handgun, evidence which would have added over two years to the defendant's sentence. ${ }^{96}$

The Seventh Circuit, in Jewel, although remanding the case on different grounds, ${ }^{97}$ confronted the same situation these four courts faced. In a concurring opinion, Judge Easterbrook put the situation in perspective.

Our case is the norm: the prosecutor charged the defendants with distributing slightly more than 5 kilograms of drugs but asked for a sentence based on more than 50 (and the court imposed a sentence based on more than 15). Where once courts sentenced the offender and not the conduct, now courts sentence for crimes that were the subject of neither charge nor

\footnotetext{
at 78 training sessions across the country." 1990 Sentencing Commission Report at 102 (cited in note 89).

94 926 F2d 321, 322 (3d Cir 1991).

95 934 F2d 1226, 1229-30 (11th Cir 1991).

96 756 F Supp at 134-35.

จ2 947 F2d at 234-35.
} 
conviction. In proving such additional crimes, illegally seized evidence may play a central role-the same sort of role it used to play in supporting convictions on additional counts. ${ }^{98}$

The prosecutors in these cases used the "relevant conduct" section of the Guidelines as a trump card when unable to get the evidence into the trial. This situation is certainly more troublesome than the situation in James, and clearly meets the James standard. Here the rules are simple and the predictions are more than mere conjecture. Here police officers have "little to lose and much to gain" by seizing the additional evidence. ${ }^{99}$

2. Cost to the truthseeking process.

The cost to the truthseeking process represents the second side of the Calandra balancing test. On the surface, distinguishing between trial and sentencing at all when applying the exclusionary rule seems odd. If a judge decides to deprive the government of the use of evidence because she finds that the government violated the Constitution to get it, an initial reaction might advocate the exclusion of such evidence for the entire criminal prosecution from start to finish. What logical distinction between trial and sentencing justifies applying the exclusionary rule at one but not at the other?

The Supreme Court answered this question, with respect to a grand jury proceeding in Calandra where it first employed the current balancing test. Stressing the grand jury's "historic role and functions," the Court noted that the grand jury "has traditionally been allowed to pursue its investigative and accusatorial functions unimpeded by the evidentiary and procedural restrictions applicable to a criminal trial." 100 Thus, in the grand jury setting, the exclusionary rule would impose a greater cost on the truthseeking process than the rule imposes at trial.

The courts that created the traditional rule exempting sentencing from the exclusionary rule used similar reasoning. As with the grand jury analysis, the courts applied the Calandra balancing test. When these courts addressed the costs side of the test, they afforded substantial weight to the historical function of the sentencing judge which they derived from Williams $v$ New York. ${ }^{101}$ More to the point, the decisions that created the traditional

\footnotetext{
${ }^{88}$ Id at 240 (Easterbrook concurring).

${ }^{99}$ James, 493 US at 319.

100 United States $v$ Calandra, 414 US 338, 348-49 (1974).

${ }^{201} 337$ US 241 (1949).
} 
rule-Vandemark and its progeny ${ }^{102}$-appealed to the authority of Williams for the distinction between sentencing and trial. ${ }^{103}$

These cases all predate the Guidelines. The four post-Guidelines "traditional rule" courts relied on these pre-Guidelines cases not only for the law, but also for the analysis that sentencing is different from trial. Lynch, Torres, and Tejada merely cited Williams and other pre-Guidelines cases, offering no functional analysis of how the Guidelines might have affected the distinction between trial and sentencing. ${ }^{104}$ McCrory explicitly stated that although Williams predates the Guidelines, its "rationale remains applicable." ${ }^{10 s}$ Since the Guidelines rejected the Williams sentencing regime, the analytical foundation upon which the post-Guidelines "traditional rule" courts depended is a hollow shell. Hence, the costs side of the exclusionary rule balancing test must be analyzed anew in the post-Guidelines world.

What costs does exclusion at post-Guidelines sentencing impose? Answering this question requires an understanding of what the Guidelines removed from sentencing and what they left intact. Before the Guidelines, the sentencing judge evaluated evidence introduced at sentencing in terms of what it said about the defendant's whole character. As an example, a sentencing judge would not add a specific amount to the sentence based on a quasi-congressional determination that the possession of a handgun in a home where the defendant sold drugs adds 154-168 months to the defendant's sentence. Instead, any such evidence provided the judge only with a more complete picture of the defendant. However, the Guidelines now preclude the judge from looking at the whole picture. With the elimination of most of the positive character considerations such as contributions in the community, reputation as an honest soul, and a stable work history, such "relevant conduct" evidence has a disproportionately negative effect.

Martha Nussbaum recently proposed that the ideal judge "sees defendants as inhabitants of a complex web of circumstances, circumstances which often, in their totality, justify mitigation of blame and/or punishment. [The ideal judge uses centrally] the notions of intention, choice, reflection, deliberation, and character

\footnotetext{
102 Vandemark, 522 F2d at 1021; Lee, 540 F2d at 1210-11; Butler, 680 F2d at 1055-56; Graves, 785 F2d at 872-73.

${ }^{103}$ Butler and Graves, while not relying directly on Williams, drew on similar understandings of the nature of sentencing. Butler, 680 F2d at 1055-56; Graves, 785 F2d at 87273.

${ }^{104}$ Lynch, 934 F2d at 1235-36; Torres, 926 F2d at 324; Tejada, 956 F2d at 1262.

$108930 \mathrm{~F} 2 \mathrm{~d}$ at 68.
} 
that are part of a non-reductive intentionalist psychology." Since giving a just sentence depends on perceiving the totality of the defendant, Nussbaum argues, "categories for mitigation should not be codified in advance for it will be impossible for such a code to anticipate adequately the countless ways in which factors interweave and bear upon one another in human reality."107

The pre-Guidelines world embodied this vision by giving the sentencing judge complete discretion, and by basing the sentence on the offender rather than on the crime. This flexible aspect of sentencing created an important distinction between trial and sentencing. When Congress removed improper considerations from sentencing through the Guidelines' "filter," they cut out the distinctive feature of sentencing. The Guidelines impose categories of mitigation and aggravation, and prevent the sentencing judge from ever perceiving the offender as anything more than a combination of several pre-selected categorical factors.

In the post-Guidelines regime, additional evidence introduced at sentencing serves the same function such evidence would serve at trial. Logically, then, excluding illegally seized evidence imposes precisely the same cost on the proceeding, whether excluded at trial or at sentencing. Consider the guns and drugs excluded at McCrory's trial. The exclusion of the illegally seized guns and drugs at trial was not costless; the exclusionary rule deprived the jury of highly probative evidence that would have helped them decide whether McCrory committed crimes relating to drug and gun possession. But with the Guidelines' matrix, the cost of exclusion at sentencing is the same as the cost of exclusion at trial, since the tainted evidence would only help with a further inquiry into the crime. The matrix system cut out the inquiry into McCrory's character. In the pre-Guidelines world, the courts could justify refusing to apply the exclusionary rule at sentencing because doing so would impair "the historic role and functions of the [sentencing hearing]." 108 But that role is now gone.

3. Deterrence and costs balanced.

Since the Guidelines' sentencing structure almost entirely undermines any deterrence gained in excluding evidence from trial in the first place, arguably one need not look to the second part of the

\footnotetext{
${ }^{108}$ Martha C. Nussbaum, Equity and Mercy 37 (paper delivered for the Dewey Lecture, University of Chicago Law School) (Apr 22, 1992) (on file with U Chi L Rev).

107 Id at 46.

${ }^{108}$ Calandra, 414 US at 349 ("sentencing hearing" superimposed over "grand jury").
} 
test. But the lack of precedent to this effect exposes the primary weakness of the arguments of the "changed circumstances" courts (in Cabrera and Rullo). They rightly pointed to a deterrence problem, but never addressed the costs side of the equation.

Viewing the Guidelines from the perspective of what they filtered out of sentencing fills the gap. Since the Guidelines eliminated the very aspect of sentencing that historically made it distinct from trial, the "costs" can only be assessed in terms of the same "costs" that accrue from excluding the same evidence at trial. These "costs" to the truthseeking process do not outweigh the need for deterrence at trial, nor should they at sentencing.

Accordingly, under the Supreme Court's current balancing test illegally seized evidence of "relevant conduct" should not be admissible at sentencing.

B. Section 3661

The "traditional rule" courts noted that Congress recodified $\S 3661$ with the Sentencing Reform Act and that $\$ 3661$ prohibits limitations on the evidence a sentencing judge may receive and consider. ${ }^{109}$ They argued that this has two implications. Either it settles the issue in favor of the traditional rule, or it shows that the costs of excluding evidence at sentencing have not changed under the Guidelines and that, consequently, the Calandra balancing test should be resolved in favor of the traditional rule.

1. Does it settle the issue?

The "traditional rule" courts raised a valid point. Section 3661 does prohibit any "limitation ... on the information concerning the background, character, and conduct" of the defendant that a sentencing judge may "receive and consider for the purpose of imposing an appropriate sentence."110 But since the exclusionary rule remedies violations of the Fourth Amendment and Congress has provided no other remedy for violations here, $\S 3661$ read broadly conflicts with the Fourth Amendment.111 If the two conflict, the Fourth Amendment wins. ${ }^{112}$ So it does not settle the issue.

Admittedly, Congress might have the power to withdraw a remedy for the Fourth Amendment in some circumstances. But to

\footnotetext{
${ }^{100}$ See $\mathrm{McC}$ rory, $930 \mathrm{~F} 2 \mathrm{~d}$ at 68.

11018 USC $\S 3661$ (1988).

${ }^{111}$ Jewel, $947 \mathrm{~F} 2 \mathrm{~d}$ at 238 (Easterbrook concurring).

112 Id.
} 
take away the exclusionary rule entirely without substituting another remedy would run squarely afoul of the constitutional basis for the rule. ${ }^{113}$ test?

2. Does it codify the costs side of the Calandra balancing

Section 3661 may "codify" the Williams vision of sentencing. This argument, found in Lynch ${ }^{114}$ and Tejada, ${ }^{115}$ suggests that $\S 3661$ preserved a tradition that favors no limitations on evidence the sentencing judge may consider. Consequently, even in the postGuidelines regime, restricting the judge's access to evidence through the exclusionary rule imposes a large cost on the truthseeking process that justifies rejecting the exclusionary rule's application at sentencing under the Calandra balancing test.

This argument might be made in two ways. The first way would see $\S 3661$ as an overarching provision that trumps the limitations of the Guidelines. Yet if $\S 3661$ trumped the Guidelines, they would accomplish very little. The argument would render the Guidelines optional.

The second version of the argument would see $\S 3661$ operating within the framework of the Guidelines. The judge may "receive" and "consider" any evidence she confronts. The Guidelines merely limit the action the judge may take after considering the evidence. This is the most plausible reading of $\S 3661$. But if the Guidelines are an effective evidentiary filter, it is hard to argue that the sentencing judge has the unlimited discretion described in Williams. By restricting the role of the sentencing judge, the Guidelines afforded her a "discretion" entirely unlike that afforded in Williams. The expansive language of $\S 3661$ may have "codified" the traditional openness of the sentencing inquiry as redefined by the Guidelines, but it did not "codify" the Williams role of the sentencing judge. That is the pivotal difference.

\section{A filtering perspective.}

It is not clear that $\S 3661$ means what it literally says. Taken literally, § 3661 would conflict with both $\S 994(\mathrm{~d})$ and $\S 994(\mathrm{e})$ of Title 28. Section 994(d) of the Code requires the Commission to "assure that the guidelines and policy statements are entirely neu-

\footnotetext{
113 Id at 239.

114934 F2d at 1235-36.

118 956 F2d at 1262-63.
} 
tral as to the race, sex, national origin, creed, and socioeconomic status of offenders." "[t]he Commission shall assure that the guidelines and policy statements, in recommending a term of imprisonment or length of a term of imprisonment, reflect the general inappropriateness of considering the education, vocational skills, employment record, family ties and responsibilities, and community ties of the defendant."117 The Sentencing Guidelines follow these § 994 limitations. ${ }^{118} \mathrm{~A}$ broad reading of $\S 3661$ conflicts with $\S 994$ on its face, invalidating the Guidelines limitations.

A filter perspective on the Guidelines properly explains the interaction. Congress recodified $\S 3661$ when it enacted the Sentencing Reform Act. Since the Sentencing Reform Act and Guidelines systematically excise evidence of character from a sentencing judge's consideration, a broad reading of $\S 3661$, which would allow a sentencing judge to "receive" and "consider" anything, would make no sense. Moreover, Congress appears to have had a higher purpose in mind than simply imposing uniformity in sentencing for uniformity's sake. The purpose behind the Guidelines-to eliminate arbitrary disparities and unequal treatment-resembles Due Process concerns. Reading $\S 3661$ to infringe on a fundamental constitutional protection against unreasonable searches and seizures would be inconsistent with Congress's purposes.

At the same time, a strict reading would not even achieve greater uniformity in sentencing. At least one study suggests that the rigid Guidelines tie the hands of judges and make prosecutors the real decisionmakers because of their choice of what to charge and what evidence to present. ${ }^{118}$ Moreover, police decisions about who to search may play a significant role in future disparities in sentencing. One commentator observed that "[t]he police are among the most important policy-makers of our entire society. And they make far more discretionary determinations in individual cases than any other class of administrators; I know of no close second." ${ }^{20}$ Another argued that "[g]iven the complex and discre-

11828 USC § 994(d) (1988).

11728 USC \$ 994(e) (1988).

${ }_{118}$ See Guidelines Manual $\S \S 5 \mathrm{H} 1.2,5 \mathrm{H} 1.5$ through 5H1.6 at $269-70$ (cited in note 31).

${ }^{110}$ See Stephen J. Schulhofer and Ilene H. Nagel, Negotiated Pleas Under the Federal Sentencing Guidelines: The First Fifteen Months, 27 Am Crim L Rev 231, 239-40 (1989).

${ }^{120}$ Kenneth Culp Davis, Discretionary Justice: A Preliminary Inquiry 222 (Louisiana State, 1969). 
tionary character of police search and seizure decisions, some limitations on this power are essential."121

Congress retained $\S 3661$ after the Guidelines solely to allow a judge to consider types of evidence not mentioned in (neither favored nor disfavored by) the Guidelines. ${ }^{122}$ Under this view, § 3661 does not apply to the normal rules of evidence; it applies only to the extent that other provisions allow judicial discretion. The Sentencing Commission's reading of $\S 3661$ adopts this view, recognizing that conflicting laws trump that section: "In determining the sentence to impose within the guideline range, or whether a departure from the guidelines is warranted, the court may consider, without limitation, any information concerning the background, character and conduct of the defendant, unless otherwise prohibited by law."123 The Commission's reading echoes the language of $\S 3661$, but it adds the limitation "unless otherwise prohibited by law." Some case law adds similar provisos. ${ }^{124}$ If another rule such as the exclusionary rule prohibits the introduction of evidence at sentencing, $\S 3661$ gives way. Such a reading reconciles the exclusionary rule with both $\S 3661$ and the reasons why Congress adopted the Sentencing Reform Act.

\section{Conclusion}

The Sentencing Reform Act replaced over a century of intuitive, character-based sentencing by handing over to the Sentencing Commission decisions about character and the discretion that accompanied them. A sentencing judge today has a new role. This new role clashes with the traditional rule that permits a sentencing judge to consider illegally seized evidence. In confronting exclusionary rule challenges at sentencing, courts are uncertain about how the Guidelines affect the balance between the deterrent effects of allowing such evidence and the costs to the sentencing process. It is not surprising that there is confusion about the impact of the Guidelines. The Sentencing Commission rewrote 150 years of sen-

121 Wayne R. LaFave, Controlling Discretion by Administrative Regulations: The Use, Misuse, and Nonuse of Police Rules and Policies in Fourth Amendment Adjudication, 89 Mich L Rev 442, 445 (1990).

${ }^{122}$ United States v Fairman, 947 F2d 1479, 1482 (11th Cir 1991), cert denied, $112 \mathrm{~S} \mathrm{Ct}$ 1503 (1992). Fairman cites $\S 1$ B1.4 of the Guidelines Manual in support of this argument. Id. Section 1B1.4 itself parallels the language of $\S 3661$. The commentary to $\S 1 \mathrm{~B} 1.4$ adds that the "court is not precluded from considering information that the guidelines do not take into account." Guidelines Manual § 1B1.4 at 21 (comment) (cited in note 31).

${ }^{123}$ Guidelines Manual § $1 \mathrm{~B} 1.4$ at 21 (emphasis added).

${ }^{124}$ See, for example, United States v Van Winrow, 951 F2d 1069, 1072 (9th Cir 1991). 
tencing law almost overnight. Viewing the Guidelines as a filter designed to remove improper factors from the sentence highlights the way sentencing in 1992 differs from sentencing in $1949 .{ }^{125}$ The new sentencing regime is focused on the crime and not the offender. This picture of sentencing allows a proper application of the Calandra balancing test which, under the new regime, requires that the exclusionary rule apply to "relevant conduct" sentence enhancements. This picture also reconciles § 3661 of the Sentencing Reform Act with the exclusionary rule.

${ }^{225} 1949$ is the year of the Williams decision, the decision that traditional rule courts applying the Calandra balancing test cited to distinguish sentencing from trial when they evaluated costs to the unique and historical function of sentencing. 
